\title{
Effect of Temperature and Photoperiod \\ on Germination and Survival
}

\section{of Sand Bluestem}

\section{J. STUBBENDIECK AND WAYNE G. McCULLY}

Highlight: Results obtained from studies with controlled environments gave an indication of responses of $G-1773$ sand bluestem (Andropogon hallii Hack.) germinating caryopses and seedlings to several different temperature and photoperiod combinations. Germination was favored by relatively high alternating temperatures and was not affected by absence of light. Survival of this accession was affected by both photoperiod and temperature. Survival was favored by 12-hour photoperiods and was inversely related to increasing temperature. These data indicate that this accession of sand bluestem may respond more favorably to fall seeding than to spring seeding.

Sand bluestem (Andropogon hallii Hack.) is an important native range grass on sandylands throughout the Great Plains and Southwest United States. It is a tall, palatable, and nutritious warm-season grass of tropical origin often used in seeding rangeland and abandoned cropland.

Many research workers have demonstrated the effects of light and temperature on seed germination, but little work has been done with sand bluestem specifically (Laude, 1956; Crocker and Barton, 1957; McGinnies, 1960; Mayer and Poljakoff-Maber, 1963; Ellern and Tadmor, 1966; Knipe, 1967). Investigators have explored also the relationships of temperature and photoperiod to plant growth and flowering,

At the time of the study, authors were assistant range scientist and professor, Department of Range Science, Texas A\&M University, College Station. The authors are currently assistant professor of agronomy (range management), University of Nebraska Panhandle Station, 4502 Avenue I, Scottsbluff 69361; and resident director, Research and Extension Center, Texas A\&M University, Vernon 76348 . The authors gratefully acknowledge Dan W. Cook for his assistance with the study.

This article is published with the approval of the director, Texas Agricultural Experiment Station, as TA-11508.

Manuscript received March 13, 1975. but little attention has been given to their effects on seedling survival (Garner and Allard, 1920; Benedict, 1940; Mitchell, 1953a and 1953b; Evans et al., 1964; Cooper and Tainton, 1968; Stubbendieck and Burzlaff, 1970).

A study was designed and initiated to determine the effect of varying temperature and the presence or absence of light on germination of sand bluestem. A second study was conducted to determine the effects of varying photoperiod and temperature on the survival of sand bluestem seedlings.

\section{Materials and Methods}

Caryopses of G-1773 ${ }^{1}$ sand bluestem that had been in storage for 12 months were separated in a seed blower and the heaviest fraction saved. Undamaged caryopses were selected after visual examination under a binocular microscope. Caryopses were treated with thiram (tetramethylthiuramdisulfide) to control pathogens during germination.

Petri dishes were used as germination containers. Two Whatman No. 3 filter papers were placed on the bottom of each Petri dish. Six milliliters of a solution of distilled water with the $\mathrm{pH}$ adjusted to 6.5 with potassium hydroxide was added to each Petri dish (Stubbendieck, 1974). One hundred caryopses were placed in each Petri dish.

Experimental design was a factorial arrangement of a randomized complete block with four replications and nine treatment combinations of temperature and photoperiod (Table 1). Seed containers were placed in a germinator having a light intensity of approximately 15,000 lux. A spectrum range of $350-800 \mathrm{~nm}$ was represented.

A separate experiment compared light and no light at alternating temperatures. Temperature combinations were 35 -

\footnotetext{
${ }^{1}$ Plant materials collected for potential drought resistance in a cooperative program with New Crops Branch, Crops Research Division, Agricultural Research Service.
} 
Table 1. Percent germination of G-1773 sand bluestem caryopses, after 28 days, at varying temperatures and photoperiods.

\begin{tabular}{|c|c|c|}
\hline \multicolumn{2}{|c|}{ Treatment combinations } & \multirow{2}{*}{$\begin{array}{c}\text { Average } \\
\text { germination } \\
(\%)\end{array}$} \\
\hline $\begin{array}{l}\text { Temperature } \\
(\mathrm{C})\end{array}$ & $\begin{array}{c}\text { Hours of } \\
\text { light }\end{array}$ & \\
\hline $\begin{array}{l}25 \\
25 \\
25 \\
30 \\
30 \\
30 \\
35 \\
35 \\
35 \\
\end{array}$ & $\begin{array}{r}8 \\
12 \\
16 \\
8 \\
12 \\
16 \\
8 \\
12 \\
16\end{array}$ & $\begin{array}{l}45 \mathrm{~b}^{1} \\
45 \mathrm{~b} \\
48 \mathrm{~b} \\
48 \mathrm{~b} \\
48 \mathrm{~b} \\
47 \mathrm{~b} \\
58 \mathrm{a} \\
58 \mathrm{a} \\
58 \mathrm{a}\end{array}$ \\
\hline
\end{tabular}

${ }^{1}$ Means followed by different letters were significantly different at the 0.05 level of probability.

25, $30-20$, and $25-15^{\circ} \mathrm{C}$. The higher temperature was programmed for 8 of each 24 hours. Approximately 15,000 lux of light was applied in conjunction with each higher temperature. All other procedures were identical to those for the germination at varying temperatures and photoperiods.

In this experiment, caryopses were considered to have germinated when both the root and shoot had attained a length of $5 \mathrm{~mm}$. Germinated seedlings were counted weekly for 4 weeks.

A second study determined the effects of temperature and photoperiod on survival of G-1773 sand bluestem seedlings. A controlled environment chamber was used in this experiment. Nine treatment combinations of constant temperatures $(25$, 30 , and $35^{\circ} \mathrm{C}$ ) and photoperiods $(8,12$, and 16 hours) were used. These were the same as used in the germination experiment. Relative humidity was maintained at $60 \%$ and light intensity at a maximum of approximately 45,000 lux throughout the experiment.

Twelve greenhouse flats $(45 \times 60 \times 10 \mathrm{~cm})$ were filled with autoclaved washed sand and placed in a controlled environment chamber for each treatment combination. Approximately 300 thiram-treated G-1773 sand bluestem caryopses were planted in each flat at a depth of $1 \mathrm{~cm}$. Sand was kept moist, and a nutrient solution was periodically applied. After all seedlings emerged, they were thinned to 200 seedlings per flat. Living seedlings were counted at weekly intervals for 10 weeks.

Experimental design was a completely randomized $3 \times 3$ factorial. Each of the three replications consisted of four flats containing a total of 800 seedlings.

\section{Results and Discussion}

Germination of sand bluestem caryopses was influenced by temperature, but not by photoperiod (Table 1). Germination was significantly higher at $35^{\circ} \mathrm{C}$ than at 30 or 25 . There were no significant differences between 28 -day germination at 30 and $25^{\circ} \mathrm{C}$.

Generally, this accession of sand bluestem germinated better in alternating than in constant temperatures, especially at higher temperature regimes (Tables 1,2 ). In the range of alternating temperature combinations used, germination increased as temperature increased. Alternating temperatures generally produce higher germination rates than do constant temperatures (Ass. Offic. Seed Analysts, 1970). Temperatures of approximately $35^{\circ} \mathrm{C}$ have been shown to favor germination of tropical grasses (Evans et al., 1964).

Some grasses require light for seed germination, but G-1773 sand bluestem did not (Table 2). Even if a light requirement existed, photoperiod may not have been a factor. The light
Table 2. Percent germination of G-1773 sand bluestem caryopses, af ter $\mathbf{2 8}$ days, at alternating temperatures with light and no light.

\begin{tabular}{ccc}
\hline $\begin{array}{c}\text { Temperatures } \\
\left({ }^{\circ}\right)\end{array}$ & Light & $\begin{array}{c}\text { Germination } \\
(\%)\end{array}$ \\
\hline $25-15$ & no & $45 \mathrm{c}^{\mathrm{i}}$ \\
$25-15$ & yes & $48 \mathrm{c}$ \\
$30-20$ & no & $65 \mathrm{~b}$ \\
$30-20$ & yes & $64 \mathrm{~b}$ \\
$35-25$ & no & $73 \mathrm{a}$ \\
$35-25$ & yes & $74 \mathrm{a}$ \\
\hline
\end{tabular}

${ }^{1}$ Means followed by different letters were significantly different at the 0.05 level of probability.

requirement for germination has been shown to be a phytochrome response. This requirement can be met by a short exposure to red light (Salisbury and Ross, 1969).

Survival of emerged seedlings is an important factor in establishment of grasses. In contrast with germination, survival of this accession was affected by both photoperiod and temperature (Table 3). The range of percent survival was longer at the two higher temperatures than at the low temperature. Unfavorable temperature frequently is listed as a cause for failure of seedlings to survive, but effect of photoperiod on survival has received little attention (Evans et al., 1964). G-1773 sand bluestem appears to be adapted to a narrow range of photoperiod.

Table 3. Average seedling survival, 10 weeks after planting, of G-1773 sand bluestem plants grown under several combinations of temperature and photoperiod.

\begin{tabular}{ccc}
\hline \multicolumn{2}{c}{ Treatment combinations } \\
$\begin{array}{c}\text { Temperature } \\
\left({ }^{\circ} \mathrm{C}\right)\end{array}$ & $\begin{array}{c}\text { Hours of } \\
\text { light }\end{array}$ & $\begin{array}{c}\text { Survival } \\
(\%)\end{array}$ \\
\hline 25 & 8 & $68 \mathrm{c}^{1}$ \\
25 & 12 & $98 \mathrm{a}$ \\
25 & 16 & $75 \mathrm{c}$ \\
30 & 8 & $20 \mathrm{~d}$ \\
30 & 12 & $86 \mathrm{~b}$ \\
30 & 16 & $24 \mathrm{~d}$ \\
35 & 8 & $0 \mathrm{e}$ \\
35 & 12 & $75 \mathrm{c}$ \\
35 & 16 & $17 \mathrm{~d}$ \\
\hline
\end{tabular}

${ }^{1}$ Means followed by different letters are significantly different at the 0.05 level of probability.

These data show survival to be best at the lowest temperature used in the experiment (Table 3). Higher temperatures favor higher rates of respiration and photosynthesis (Salisbury and Ross, 1969). It is postulated that rates of respiration under conditons of this experiment were higher in relation to rates of photosynthesis at 30 and $35^{\circ} \mathrm{C}$. Rates of respiration at higher temperatures apparently caused the death of large numbers of seedlings.

\section{Conclusions}

High temperatures favored germination, but low temperatures favored survival of this accession of sand bluestem. It may not be best adapted to spring seeding and may partially explain the high incidence of range seeding failures. If moisture is adequate, late summer or early fall seeding may maximize establishment of G-1773 sand bluestem. Soil temperatures at seeding would be relatively high and would promote maximum germination. Decreasing soil temperatures in the fall would favor seedling survival. Photoperiod also 
would be declining in the fall and would be approaching optimum. Seeding in spring would subject developing seedlings to increasing photoperiods and temperatures which would be beyond optimum for survival.

\section{Literature Cited}

Association of Official Seed Analysts (Rules Committee). 1970. Rules for testing seeds. Proc. Ass. of Offic. Seed Anal. 60:116.

Benedict, H. M. 1940. Effect of daylength and temperature on the flowering and growth of four species of grasses. J. Agr. Res. 61:661-671.

Cooper, J. R., and N. M. Tainton. 1968. Light and temperature requirements for the growth of tropical and tempera te grasses. Herb. Abstr. 38:167-176.

Crocker, W., and L. V. Barton. 1957. Physiology of secds. Chronica Botanica Co., Waltham, Mass. 249 p.

Ellern, S. J., and N. H. Tadmor. 1966. Germination of range plant seeds at fixed temperatures. J. Range Manage. 19:341-345.

Evans, L. T., J. F. Wardlaw, and C. N. Williams. 1964. Environmental control of growth, p. 102-125. In: Grasses and grasslands. C. Barnard, Ed. Macmillan \& Co., Ltd., London.
Garner, W. W., and H. A. Allard. 1920. Effects of relative growth and reproduction in plants. J. Agr. Res. 18:553-606.

Knipe, O. D. 1967. Influence of temperature on germination of some range grasses. J. Range Manage. 20:298-299.

Laude, H. M. 1956. Seedling emergence of grasses as affected by low temperature. Agron. J. 48:558-560.

Mayer, A. M., and A. Poljakoff-Maber. 1963. The germination of seeds. The Macmillan Co., N.Y. 236 p.

Mitchell, K. J. 1953a. Influence of light and temperature on the growth of ryegrass (Lolium spp.). 1. Pattern of vegetative development. Physiol. Plantarum. 6:21-46.

Mitchell, K.J. 1953b. Influence of light and temperature on the growth of ryegrass (Lolium spp.). 2. The control of lateral bud development. Physiol. Plan tarum. 6:425-443.

McGinnies, W. J. 1960. Effects of moisture stress and temperature on germination of six range grasses. Agron. J. 52:159-162.

Salisbury, Frank B., and Cleon Ross. 1969. Plant physiology. Wadsworth Publ. Co., Inc., Belmont, Calif. 747 p.

Stubbendieck, J. 1974. Effect of $\mathrm{pH}$ on germination of three grass species. J. Range Manage. 27:78-79.

Stubbendieck, J., and D. F. Burzlaff. 1970. Effects of temperature and daylength on axillary bud and tiller development in blue grama. $J$. Range Manage. 23:63-66. 